\title{
The Effect of Increased UV-B Radiation on the Terrestrial Ecosystem
}

\author{
Mehtap Gürsoy ${ }^{1, a, *}$ \\ ${ }^{I}$ Güzelyurt Vocational School, Aksaray University, 68500 Güzelyurt/Aksaray, Turkey \\ *Corresponding author

\begin{tabular}{l|l} 
A R T I C L E I N F O & A B S T R A C T \\
\hline Review Article & $\begin{array}{l}\text { Against rapidly developing industry and increasing population, natural resources on earth are getting } \\
\text { destroyed. One of the most important adverse effects on the environment is perhaps the depletion of } \\
\text { ozone layer which protects the earth from harmful effects of UV radiation, especially UV-B. The } \\
\text { effect of UV-B radiation can vary according to species. At high rates of UV-B radiation, many } \\
\text { disorders in DNA, photosynthesis, morphological and physiological structure, and biomass } \\
\text { accumulation in plants are observed. In this review, the effects of high UV-B radiation on terrestrial } \\
\text { ecosystem are discussed. }\end{array}$ \\
$\begin{array}{l}\text { Accepted : 01/07/2019 } \\
\text { Aeceived : }\end{array}$
\end{tabular}

Keywords:

UV-B radiation

Terrestrial ecosystem

Ozone layer depletion

Environment

Physiological structure

mehtapgrsoy@gmail.com

(i) https://orcid.org/0000-0002-7764-5259|

(c) (1) (2) This work is licensed under Creative Commons Attribution 4.0 International License

\section{Introduction}

In parallel with the population increase after the Second World War, in return for the increasing food consumption fast, by virtue of not being able to increase food production, a problem of inadequate and unbalanced nutrition has occurred (Y1ldiz, 1995). According to the reports of United Nations Food and Agriculture Organization (FAO), food production in the countries of Asia, Africa, and Latin America has increased 2-3 times in the last 30 years. However, production has fallen behind the population growth rate, and unfair distribution of the current crop has caused the inadequate nutrition of the $1 / 5$ of population. While 24 million babies are born at a weight below the line in a year, 13 million people most of which are children starve every year.

The fast industrialization observed after the second half of the $20^{\text {th }}$ century, great technological development, and population increase have created the fast and careless consumption of the natural resources of our world, environmental pollution, and damage to the atmosphere surrounding the earth. When the pollution and the importance of the damages occurred as result of it is understood, environmental problems have been the outstanding ones of the world. These problems were dealt with at the beginning in term of the immediate environment, then it has been obligatory to deal with the problems nationally, continentally, and finally globally.
All damages and many other examples to be able to get given have been due to the fact that human being exploits nature only according to his own interests unilaterally. Unfortunately, ecological balance has been damaged more or less everywhere human being lives throughout history. Resources have been irremediably used, and their new alternatives couldn't be substituted. In fact, the environmental problems which are quite current today isn't the fact that has just appeared. However, starvation and poor nutrition problem has increased because of the fast population increase in the last century and the agricultural lands' being just to end, and due to the familiar reasons, so it has reached at the dimensions that threatens the living in the world. All these problems happening in the field of environment today has elicited the result that the damages created by human being throughout history knowingly or unknowingly increase much more.

Today, it is understood that all the resources the human being uses have decreased, been damaged, or their function has been interrupted. In this essay, it has been investigated how the damage that occurred in the atmosphere has effected the earth as the result of some chemical substances which are used in industry.

Important depletions were determined on the total ozone extent on a global scale between 1979 and 2010. This depletion increases the ultraviolet radiation (UV-B) arriving on the earth (280-315 $\mathrm{nm})$. 
The atmosphere is classified to 4 layers which are troposphere, stratosphere, mesosphere, and thermosphere. There are also 3 transition layers in the atmosphere other than these named tropopause, stratopause, and mezopause. Global average temperature is $15^{\circ} \mathrm{C}$ in the regions near the earth surface. This temperature in troposphere which is the rock bottom layer of the atmosphere decreases $6^{\circ} \mathrm{C}$ for each kilometer. Thus, the temperature in tropopause which is the peak of troposphere decreases to $-55^{\circ} \mathrm{C}$. Weather events happen in this layer. More than $85 \%$ of the total air mass exists here. Stratosphere which is the next layer exists between the heights $10 \mathrm{~km}$ and $50 \mathrm{~km}$. The temperature which is $-55^{\circ} \mathrm{C}$ in tropopause reaches at $0^{\circ} \mathrm{C}$ increasing in stratopause which is the peak of stratosphere. The reason for this temperature increase in stratosphere layer is that solar rays (especially the UV-B rays having high energy) are absorbed. About $90 \%$ of the amount of total ozone exists in stratosphere and in the region $20-30 \mathrm{~km}$ high.

Since the ozone layer keeps the ultraviolet rays of sun under $300 \mathrm{~nm}$ wave lengths that is dangerous for living on the earth, it plays a very significant role. Ozone exists in an amount which is less than one millionth (1/1 000000$)$ of the total of all the other gases existing in the atmosphere. The ozone the chemical formula of which is $\mathrm{O}_{3}$, is also called as a kind of super oxygen. Ozone is benefitted from in different sectors in daily life. For instance, ozone is widely used to disinfect the city waters, in solid and liquid oils, to lighten the cloth colours, and to eliminate the bad tastes. It takes place in the air we breathe sparingly, and its original odour is felt in the stormy air and around the devices having high voltage. When it exists in high amount around us, it causes the lungs and all the mucosas to get destroyed. It shortens the life of plants by effecting the photosynthesis. Furthermore, it causes the plastic and rubber based materials to get decayed. The same ozone plays a role of rescuer for the life on the earth when it exists in the high layers of the atmosphere and especially in stratosphere.

There are many gases destroying the ozone layer in stratosphere. As an example, $\mathrm{N}$-originated gases produced by ground bacteria, $\mathrm{CO}$ occurring through the fossil fuels (coal, petroleum etc.), nitrogen oxides, water vapour, and $\mathrm{CH}_{4}$ gas constituting from the spoiling organic substances can be given. However, the dissolution created by these gases in the ozone layer is repaired over time. Anyhow, the scientific data indicates that the gases including chlorofluorocarbon (CFC) destroy the ozone layer beyond repair. $\mathrm{CFC}$ gases were considered as a great innovation when they were put into use about 30 years ago, because these gases neither were burnable, explosive and toxic nor reacted to any substance chemically. These properties have caused CFC's to get widely used in industry for many years. These gases don't spoil due to their same features when they are mixed to the air and stay in the atmosphere for many years. However, they start to spoil and constitute chemical reaction at $-85^{\circ} \mathrm{C}$ when they move away from stratosphere. Therefore, it causes for them to be a problem perhaps to end the earth. CFC gases are used in industry as propellant in sprays, the cooling and isolation substance in the refrigerators, cooling in air-condition systems, cleaning agent in electronic industry and the substance to produce solid and soft foam.
Mesosphere, which is the next layer, exists at the heights between 50-85 km. Temperature decreases again here with the height, and decreases to $-80^{\circ} \mathrm{C}$ in mezopause. The temperature in thermosphere, which is the topcoat, increases again with the height. These gases which are quite stable in the conditions of earth and troposphere chemically survive for 100 years in atmosphere. It has been specified that they go to the underside of stratosphere within a few years by the emission current into the atmosphere and reach at the middle of stratosphere where ozone $\left(\mathrm{O}_{3}\right)$ intensity is the most a few years later. Since ultraviolet radiation is severe in stratosphere, $\mathrm{Cl}$ and $\mathrm{ClO}$ radicals constitute from these gases as the result of photodissociation. It is known that only CFC molecule demolishes 100000 ozone molecules during its entire lifetime catalytically. Nowadays, $\mathrm{Cl}$ concentration in stratosphere has indicated a 5 time increase in contrast with the period before CFC gases are started to get produce. CFC gases also contribute the greenhouse effect and have influence 10000 times more than $\mathrm{CO}_{2}$. Despite their concentration are less, they act at global warming at the rate of $15-20 \%$. As the result of this increase, raises can happen at the levels of sea by the melting glaciers. Climatic variation will indicate wide changes amongst the regions, aridification will occur in the regions near equator, and flood disasters will happen oftener on the higher latitudes because of the increased rain.

\section{UV-B Radiation and Its Characteristics}

The main resource of ultraviolet radiation is sun. However, this radiation can also be constituted as artificial. In the industry of artificial ultraviolet radiation is used in the hospitals as disinfectant, in biology laboratories, and in the schools. Ultraviolet radiation is the radiation that the electromagnetic radiations don't constitute ionization and the wave length of which is between 200-400 nm. This radiation is branched as ultraviolet-A (UV-A), ultraviolet $\mathrm{B}$ (UV-B), and ultraviolet-C (UV-C) regions. UV-C region is the $200-280 \mathrm{~nm}$ wave length rays. Since the radiation coming from the sun having the wave length under $290 \mathrm{~nm}$ is absorbed by stratospheric ozone layer, they can't reach at the living organisms. There are rays in UV-B region having 280-320 $\mathrm{nm}$ wave length, and they have got important effects on the living creatures. On the other hand, UV-A includes the rays having 320-400 nm wave length. There isn't enough information about the biological effects of this radiation. The most important obstacle in front of the cosmic radiation is atmosphere on the earth. Especially the ozone layer in stratosphere constitutes an important obstacle for the radiation having 200-300 nm wave length.

The depletion in ozone layer at the $1 \%$ level causes a $2 \%$ increase at the high energy UV-B radiation. In general, since the short wave length radiations are absorbed by ozone, they cannot reach on the earth. However, as the result of crashed ozone, the increase at UV-B level constitutes negative effects on the several life zones on the earth. 280-315 $\mathrm{nm}$ wave length UV-B radiation has got many effects on human being. Some of these effects are the positive ones like constituting vitamin D in the skin. A sort of bone illness named Rachitism happens especially amongst children in the lack of vitamin D. However, the effect of UV-B radiation over human being is generally 
negative. Sunburn, cataract, skin aging, and skin cancer are some of these negative effects. The increase of UV-B effects the immune system in negative way, and it causes the infectious diseases get progressed. It is accepted by the scientists that a great increase has happened at the diseases concerning the immune disorder in the last 10 years isn't coincidence. Furthermore, the increase of UV-B rays causes many diseases like measles, varicella, dermatitis, malaria, tuberculosis, and fungal infections get repeated, and occurring severely.

The small organisms especially like phytoplankton and zooplankton are extremely affected by the increase of UV$B$ radiation. Since these organisms constitute a very important ring of the food chain existing in the seas, the increasing UV-B radiation makes a negative effect on the current fish existence. Furthermore, the phytoplankton's existing in the oceans take place amongst the important consumers of $\mathrm{CO}_{2}$ in the atmosphere. Therefore, decrease of them causes the greenhouse effect dispersed as result of the increasing $\mathrm{CO}_{2}$ concentration in the atmosphere.

Being exposed to UV-B radiation makes negative effects on material. Especially extinction speed of rubber products increases. Furthermore, paint, wood, paper, and textile products are also negatively affected by UV-B radiation.

\section{The Effect of UV-B Radiation on Plants}

The physiological and development events of plants are effected by UV-B radiation. Within the 20 years after the first report revealing the decrease of stratospheric ozone, more than 350 researches have been performed about the effects of UV-B (280-315 nm) radiation on plants. However, most of them are the researches carried out by the agricultural plants in laboratory and greenhouse conditions, and less than $5 \%$ of them have been performed in field conditions. A few of them are related to the forest and the other non-agricultural plants (Caldwell and Flint, 1994). Although laboratory and greenhouse studies give information about UV-B radiation, realistic results can only be taken from field tests, because the radiation conditions in the laboratories and greenhouses are quite different from the field conditions. Controlling the factors affecting the plant growth and development in the covered areas like laboratory and greenhouse is much easier than the open areas like field which is open to every sort of climate incidents. In the circumstances, adjudicating according to a research result by considering only one factor eliminating the other factors can cause big mistakes. Being able to determine what sort of effects UV-B radiation creates on plants accurately is possible by contextualizing all the factors effecting plant growing and developing, because natural events and occur by various factors' gathering. Hence, the rates of UV-B, UV-A and PAR (Photosynthetic Active Radiation) at the studies in the laboratories and greenhouses are quite different from field conditions. When the rates of UV-A and PAR are low, the effect of UV-B can be more severe.

Adverse effects of the increasing UV-B radiation on plants can be listed as damage to DNA, preventing photosynthesis, and the changes at morphological and phenological structures and biomass accumulation (Bornman and Teramura, 1993).These effects of UV-B radiation on plants change based on the type, species, development situation, and development conditions of plants. The plants like soybean, cucumber, peas, bean, and sunflower can be listed amongst the very sensitive agricultural crops.

The most important effect of the increasing UV-B radiation is the permanent spoiling in DNA. Since the ones of UV-B rays having $260 \mathrm{~nm}$ wave length are absorbed by DNA, they have got the most severe effect. The harmful effect of UV rays and especially UV-B group rays on DNA is due to the neighbour pyrimidine's combining some of them to one another and preventing their functions. Thymine is the most affected one by UV radiation. The two bases existing side by side in DNA helix combine with the effect of UV radiation as Thymine-dimer (Düzgüneş and Ekingen, 1983). This structure causes spoiling in DNA double helix, so it induces DNA's not being able to perform its function. In addition, one of the harmful effects of UV-B radiation on DNA is caused by vitamins getting destroyed acting in DNA synthesis.

UV-B radiation has got a negative effect on photosynthesis by decreasing the chlorophyll content of the leaves (Strid et al., 1990).

Indeed, the molecular foundations of many changes seen in the plants exposed to UV-B radiation haven't been completely understood yet. UV-B radiation have got important effects on the anatomic structure of plant. $45 \%$ increase has been seen at the leaf thickness of the plants exposed to UV-B radiation, $21 \%$ increase in the content of pigment, and the content of chlorophyll has been decreased (Bornman and Vogelmann, 1991). It was seen that the leaf area of many plants has receded under UV-B radiation (Tevini and Teramura, 1989; Johanson et al., 1994). Important decreases have been reported in the total biomass and leaf area of 16 rice cultivars under UV-B radiation (Teramura et al., 1991). Deckmyn et al. (1994), grew bean plants of cv. 'Label' under 6 different light applications in order to determine the sensitiveness of UVB levels. The different radiation levels caused great changes at the total dry matter, leaf weight, photosynthesis and pigment concentration. $15 \%$ increase of UV-B radiation has caused $24.5-34.3 \%$ decrease at the total dry matter, and also affected the photosynthesis in negative way. It has been determined that the protective pigment accumulation in the leaves is closely related with the total radiation level.

Gislefoss et al. (1992), investigated the protective mechanisms of leek (Allium ampeloprasum L.) and cabbage (Brassica oleracea L.) against the harmful UV-B radiation. Cultivars 'Alma' from leek and 'Kvislar' from cabbage were grown in the greenhouse under UV-B radiation for 4 hours a day, the changes at the optical characteristics like the light transmittance in epidermis and flavonoid content were recorded. When the plants subjected to UV-B radiation, important increases have occurred at the pigments absorbing UV.

Ziska and Teramura (1992) grew the 'IR-36' and 'Fujiyama-5' cultivars of rice in greenhouse at their normal and high $\mathrm{CO}_{2}$ concentrations from germination to generative stage under the UV-B radiation that $25 \%$ stratospheric ozone loss would create. The high $\mathrm{CO}_{2}$ concentration has decreased the night respiration considerably, and photosynthesis, while total biomass and yield have been increased in both cultivars. 
Murali and Teramura (1986) grew two soybean cultivars in 1983 and 1984 at the two levels of biological active UV-B radiation constituted as the result of $16 \%$ and $25 \%$ ozone depletion. $\mathrm{CO}_{2}$ assimilation, respiration, stomatal transmissivity and leaf water potential were affected significantly under the irradiation of UV-B. In another study conducted by the same researchers, the effect of biologically effected UV-B radiation in 23 soybean cultivars under greenhouse conditions until the generative maturity was examined. Six of these cultivars have been grown at the similar UV-B levels on the field conditions. UV-B sensitivity based on the vegetative characters became similar on the field and greenhouse conditions, while the sensitivity based on seed yield was significantly different.

UV-B radiation is also effective on flowering time and number of flowers (Caldwell, 1968; Ziska et al., 1992). The plant reproductivity parts such as pollen and ovarium are sheltering against UV-B radiation. For example, anther walls can absorb $98 \%$ of the coming UV-B rays. Pollen walls also includes the compounds absorbing UV-B radiation. However, pollen is sensitive against UV-B radiation after it moves to stigma and get germinated (Flint and Caldwell, 1984).

\section{The Reaction of Plants against UV-B Radiation}

Penetration of UV-B rays into the plant is determined by the structural and biochemical changes happening in the plant body. For instance, pigments, especially flavonoids that exist in cellularly juice and give white-red color and some phenolic compounds decrease UV-B radiation's entering into lower layers. Plant species differs according to the ability of synthesising the pigments which absorb UV-B radiation (Tevini et al., 1991). UV-B entrance is the highest at herbaceous broad-leafed dicotyledonous, and is lower at woody dicotyledonous, grasses and conifers (Day et al., 1992). UV-B entrance also changes according to the leaf age. Old leaves are more sensitive than young ones against UV-B radiation. Moreover, waxy layer in the leaf is also an important factor decreasing UV-B entrance to the tissue (Robberecht et al., 1980). The tall or number increase in the internal leaf cells affects UV-B entrance in palizadic and mesophilic cell layer.

The DNA's which are damaged by UV-B radiation are repaired by the excreted DNA photolaz (DNA repair) enzyme. This enzyme is catalysed by ligase and polymerase enzymes. This enzyme decreases the damages in genetic material caused by radiation other mutagenic factors. The amount of DNA photolaz enzyme in the plant increases with UV-B.

\section{Conclusion}

As it is understood from all these subjects described so far, UV-B radiation is extremely dangerous for living on the earth. Therefore, using the chemical substances that destroy the atmosphere has to be limited as soon as possible, even it should be stopped. Hence, laws must be legislated if it is necessary, and the subject ought to be brought under control by laws. Otherwise, unrepairable results can come up.

\section{References}

Bornman JF, Vogelmann TC. 1991. Effect of UV-B radiation on leaf optical properties measured with fibre optics. J. Exp. Bot., 42:547-554.

Bornman JF, Teramura AH. 1993. Effects of ultraviolet-B radiation on terrestrial plants. Environmental UVPhotobiology, 427-471.

Caldwell MM. 1968. Solar ultraviolet radiation as an ecological factor for alpine plants. Ecological Monographs, 38: 243-268.

Caldwell MM, Flint SD. 1994. Stratosferic ozone reduction, solar UV-B radiation and terrestrial ecosystems. Climatic Change.

Day T A, Vogelmann T C, and Delucia E H. 1992. Are some plant life forms more effective than others in screening out ultraviolet-B radiation. Ecologia., 92: 513-519.

Deckmy G, Martens C, Impens I. 1994. The importance of the ratio UV-B/photosynthetic active radiation (PAR) during leaf development as determining factor of plant sensitivity to increased UV-B irradiance; effects on growth, gas exchange and pigmentation of bean plants (Phaseolus vulgaris cv. Label). Plant, Cell and Environment, 17:3, 295-301.

Düzgüneş O, Ekingen HR. 1983. Genetik. Ankara ÜniversitesiZiraatFakültesiYayınları: 555, Ders Kitabı:187, Ankara.

Flint SD, Caldwell MM. 1984. Partial inhibition of in vitro pollen germination by simulated solar ultraviolet-B radiation. Ecology, 65: 792-795.

Gislefoss JS, Kjeldsstad B, Bakken AK. 1992. Optical properties of the epidermis of leek (Allium ampeloprasum L.) and cabbage (Brassica oleracea L.) after enhanced ulltraviolet-B radiation. Soil and Plant Science, 42:3, 173-176.

Johanson U, Gehrke C, Björn LO, Callaghan TV, Sonnesson M. 1994. The effects of enhanced UV-B radiation on a subarctic heath system. Ambio.

Murali NS, Teramura AH. 1986. Effects of supplemental ultraviolet-B radiation on the growth and physiology of fieldgrown soybean. Environmental and Experimental Botany, 26:1, 89-95.

Robberecht R, Caldwell MM, Billıngs WD. 1980. Leaf ultraviolet optical properties along a latitude gradient in the arctic-alpine life zone. Ecology, 61: 612-619.

Strid A, Chow WS, Anderson JM. 1990. Effects of supplementary ultraviolet-B radiation on photosynthesis in Pisumsativum. Bioenergetics, 1020:3, 260-268.

Teramura AH, Ziska LH, Sztein AE. 1991. Changes in growth and photosynthetic capacity of rice with increased UV-B radiation. Physiologia Plantarum, 83: 373-380.

Tevini M, Teramura AH. 1989. UV-B effects on terrestrial plants. Photo-chemistry and Photobiology, 50:479-487.

Tevini M, Mark U, Sa1le-Mark M. 1991. Effects of enhanced solar UV-B radiation on growth and function of crop plants seedlings. Current Topics in Plant Biochemistry and Physiology, 10: 13-31.

Yıldız M. 1995. Tarımsal Üretim Artışında ve Açlık Probleminin Çözümünde Biyoteknolojiden Yararlanma İmkânları ve Şeker Pancarındaki Uygulamaları. KarıncaKooperatifPostası, Ankara, Sayı: 706.

Ziska LH, Teramura AH. 1992. $\mathrm{CO}_{2}$ enhancement of growth and photosynthesis in rice (Oryzasativa). Plant Physiology, 99:2, 473-481.

Z1ska LH, Teramura AH, Sullıvan JH. 1992. Physiological sensitivity of plants along an elevational gradients to UV-B radiation. American Journal of Botany, 79: 863-871. 